\title{
PREFACE
}

\section{By Way of Introduction}

The argument of this book is carried on at three interrelated levels. First, I contend that the problem of "mimesis" helps to unfold dimensions of hermeneutical reflection. In the exploring of it, the concerns and contributions of important theorists come to light. More specifically, I undertake a reading of the works of Hans-Georg Gadamer, Paul Ricoeur, and Søren Kierkegaard in two ways. First, I explore what I call the "mimetic strategies" of these thinkers relative to the classical and Enlightenment uses of imitation theory now under criticism. My claim is that any thinking beyond imitation requires undoing and reconstructing mimesis vis-à-vis the problems that imitation was used to conceptualize and address. These problems ranged from aesthetics to metaphysics, but they centered on understanding and language, truth claims, and the formation of the moral agent. Accordingly, I examine Gadamer's hermeneutic of understanding and language, Ricoeur's theory of narrative as a paradigmatic case of the mimetic power of language, and Kierkegaard's claims about human passion and existence relative to the imitatio Christi.

My concern in these chapters is to grasp the shape and texture of each position in relation to the problematic of mimesis. These readings are not extensive commentaries on the thinkers in question with respect to their dependency on and departure from other major figures, like Kant or Heidegger. That kind of scholarship is best left to works dedicated to an individual thinker. Yet I do argue that mimesis does open up a fruitful reading of the thinkers in question.

Second, the book attempts to reclaim the notion of mimesis as crucial for contemporary reflection. Of course, the very idea of critically reclaiming questions, problems, and ideas is suspect in much current philosophical and theological discourse, especially when such reclaiming is taken to mean repristinating past ideas and concepts. Thought cannot re-enact past modes of reflection untainted by its own historicity; ideas, concepts, and forms of discourse cannot simply be reduplicated in different historical contexts by different minds without some consequence for their meaning. A romantic return to the past is not possible for those like us who are mired in time and language.

Mindful of the historicity of understanding and the other that remains other, hermeneutical reflection seeks to understand that which is different. More to the point, it seeks to understand what is covered up, even what we think is 
most evident and obvious. Therefore, when I say that the second task of this book is the critical reconstruction of mimesis, I clearly do not mean a return to lost origins or a repristination of past ideas. Of course, to be mired in time and language does mean that the past has effects on the present. There will be continuity as well as discontinuity in the reading of mimesis I am proposing. Yet given that, what I am undertaking is an alternative interpretation of mimesis enriched by contemporary critiques seeking to inform the task of reflection. I think that the current criticism of mimesis and the manifold forms of antimimetic thought have diverted us from what is covered up, even though it is close to us - as close as our own understanding, action, and the struggle to be selves with others.

The pressing question for this second level of my argument is then: Why mimesis? I contend that it is a valuable interpretive key to current hermeneutics, theology, and ethics because it crosses through the array of problems now facing us. These are questions about meaning and power relative to language and understanding, text, and personal existence. The fragmentation that marks the postmodern ethos, a dissemination regarding language, self, and world, is understandable in part as the breakdown of classical and modernist mimeticism. Thus I am simultaneously employing mimesis as a clue both for reading postmodern thinkers and for critically reconsidering its hermeneutical import for current thought.

As a work in hermeneutics there is a bit of irony in the book's title. Mimesis has often been used to speak about thinking or art as an activity of copying or mirroring what is under question, and "reflection" also has been taken to imply that mental acts "reflect" and "refract" the world they represent through ideas and images, themselves "mirrors" of reality. Thus the title of the book seems to suggest a form of realistic thinking currently under attack by theologians and philosophers as well as literary theorists and cultural critics. The irony is that the reconstruction of mimesis I undertake provides the means for the deconstruction of imitative thought about language, understanding, and the human condition. At least this is my argument.

But there is more. To title this text Mimetic Reflections is to suggest that current thinkers continue to wrestle with the problem of understanding a meaningful world, the relation of time and action, and the task of being a self. And it is to claim that these are questions we should continue to explore. The book carries on an inquiry into these problems by attempting to think with and yet beyond previous ways of considering them. The reason for this approach is simply that our thinking cannot escape the past even as it seeks to address the specific questions that confront us now. The concern of this study is to explore the ways we think and speak about the human condition in all its complexity and ambiguity. Such thinking arises out of and returns to the welter of life or it becomes vacuous and pointless. Our interpretations, in other words, must wrestle with the claims of others and the world. 
This leads to the third level of my argument. The final concern of this book is not simply to reconstruct mimesis and provide a reading of current thinkers. It is to make a modest proposal for ways of thinking theologically and ethically about the questions we face. Of course, in this book I do not attempt to put forward a comprehensive construal of the being and activity of "God," the status, import, and possibility of such thinking and speaking, or the relation of the divine to world and human being and doing. In short, this is not a theology. Nor is it an ethic. I have not attempted a comprehensive account of the meaning and value of human being and doing, modes of practical reasoning, or the examination of ways of life relative to an articulable measure of the well-lived life. Nevertheless, though this work is not a theology or an ethic, it is oriented by them and seeks to provide a mode of reflection to help carry them out.

At present there is considerable suspicion about the relation of hermeneutics to theology and ethics. On the one hand, there are theologians who argue that reflection on the status of theological and ethical discourse removed from the particularities of a community's narratives begins in error. These critics hold that hermeneutical reflection necessarily takes human being-in-the-world as the subject matter of any text, including religious ones. Given this, a hermeneutically informed theology becomes an interpretation of existential questions, reducing without remainder religious beliefs and symbols to present concerns. On the other hand, there are thinkers who claim that all hermeneutical reflection will, by the nature of the case, undo itself, given the playful character of language. To claim that reflection on the way we think and speak about human being and doing will advance any constructive understanding of the human project or of the divine is naïve. The task, these critics claim, is to deconstruct our pretenses to such projects.

It is important to note that mimesis is central to each of these criticisms of hermeneutics. And my own substantive argument will draw on insights from each. However, I contest their conclusions about the kind of inquiry this work must represent. Hermeneutical reflection, as I use the term, is indeed concerned with human being and doing, but it also seeks to understand what confronts us as different and other, whether that other is the Word of God, the face of the poor, or the strange claims of the past. It is concerned with the Sache, the subject matter, in question, but always in relation to some interpreter. And because this kind of reflection is a form of practical thinking, it is not reducible to the structure and play of sign systems. Hermeneutical thinking is irreducibly tied to the problems of life. Such reflection does not necessarily attempt to escape or control our finitude; nor must it attempt to reduce all texts and traditions to existentialist questions about the meaning of authentic human life as an act of freedom. It is a way of carrying on the task of theological and ethical reflection. However, regarding the third level of the argument, the constructive one, the question returns: Why mimesis? Beyond 
the presence of mimetic strategies in current forms of theological and ethical reflection, why consider it in the constructive task of thought?

As has often been noted, theologians currently face a twofold "crisis" regarding the status and import of their reflection: a crisis of cognitive claims about the truth and meaningfulness of religious discourse, and a crisis of praxis relative to religious symbols, beliefs, and claims about human moral and political existence. If nothing else, this dual problematic means that for any theology to be persuasive it must surmount the separation of theology and ethics and struggle to be truly theological and truly ethical. As one step in this direction, I have attempted in this book to unfold a set of questions and to develop a mode of reflection that can address these issues on their own grounds and in their own way.

Thus mimesis is important for the task of theological and ethical reflection because it signals a constellation of problems inherent in Western discourse about the divine and human life. This tradition has become gravely problematic and even oppressive for most, if not all, of us. I contend that its problematic and heteronomous character is related in great part to classical and modern mimeticisms. Yet even the notion of a "tradition" poses difficulties. Given this, the task of thinking with and beyond received problems and modes of discourse is both a challenge and a necessity: a challenge because what has been bequeathed us is not sufficient to meet our questions; and a necessity because thought is irreducibly finite and mired in time and language. Taking up this challenge and that necessity is the task of any hermeneutically informed mode of reflection, whether in theology and ethics or not. It is the form of thinking I am attempting to practice in this work.

Obviously, any critical and reflective work is undertaken from some perspective or point of view. This is certainly the case with the present work. My standpoint is mentioned and employed throughout even as the argument seeks to unfold some of its import. It entails the contention that knowledge of the human condition cannot simply be derived from theological claims or religious narratives, and that discourse about the divine is not easily reduced to claims about authentic human being and doing or the natural world. Given this, the argument seeks to unfold those practices crucial for understanding the human condition, even as these imply the question of our relation to the divine as that in which we live, move, and have our being. This stance, which entails substantive and interpretive claims, is hardly unproblematic. However, it is crucial if we are to make any sense of the symbol "God," the human experience of the divine, religious and moral discourse, and the complex character of the human condition. At least this is what part of my argument tries to show.

The specific stance and mode of reflection that I seek to practice in this work helps to explain why I have chosen to explore the thinkers I have. After all, it might appear odd to read hermeneutical thinkers on the way to theology and ethics. Of those I explore in depth only Kierkegaard is customarily called 
a theologian. Yet since I am trying to explore questions that permeate the ways we think and speak about human being and doing with others and in relation to the divine, it is necessary to explore those thinkers who directly address these issues. This is all the more the case regarding mimesis. Thus the task of reconstructing mimesis and contributing to theology and ethics has shaped my selection of thinkers to consider. Any constructive work in theology and ethics along these lines must finally think beyond those whom I have explored here. It must also, I believe, think with them.

This book seeks, then, to carry on an argument at three interrelated levels. It is a contribution to understanding central postmodern thinkers, the reconstruction of an important notion in our intellectual and cultural traditions, and a step toward the tasks of theology and ethics. In the end it remains inconclusive while indicating a direction of thought and a set of problems that I think must be explored by theologians, philosophers, literary theorists, and cultural critics. If my argument is found persuasive, my hope is to follow this direction of inquiry further and to explore the problems that still call for some response. 

Mimetic Reflections 
